\title{
Garpenberg-the success story by Rolf Jonsson
}

\section{Published by Boliden Mineral, Umeå Sweden 2014}

\author{
Magnus Ericsson ${ }^{1}$
}

Published online: 1 June 2016

(C) Springer-Verlag Berlin Heidelberg 2016

In my previous book review of the unique "Malmletarna" (The Prospectors), featured in Mineral Economics 2015 (1-2, p 79) and also published by the Swedish mid-sized miner Boliden, I called the then illustrated collective exploration effort "a model for all types of companies, not only mining companies and their exploration departments." Obviously, Boliden found the results of the first book exiting too and directly decided to venture into a new exploration story: this time in English and digging into details of the exploration work at its Garpenberg gold/silver/ copper/lead/zinc mine in central Sweden.

Garpenberg is originally a medieval mine perhaps going as far back as the tenth century. Its very name which consists of two parts "garp" and "berg" in itself gives some indications of its early days: Garp is an ancient Swedish word for a German person and berg, in this setting, denotes an area where a specific mining law rules.

In spite of, or perhaps rather because of, its old origins and long life, the mine was facing close down in the 1990s. A brainstorming session organized in 1994 came to the conclusion that the mine would be depleted in 2001, and to prevent this, a major new discovery was needed by 1998 . Only 3 years to develop a new deposit today sounds incredibly optimistic. But Boliden's geol- ogist managed to do so, and between 1997 and 2001, four new deposits were discovered. It started with Gransjön, then Kaspersbo and Lappberget and 2 years later Kvarnberget. "At a time when the financial crisis and the Bre-X-scandal had almost knocked out the entire mining industry, these four deposits were found in Garpenberg and possibly saved Boliden's future" as it is put on the back cover of the book. In 2015, Boliden completed a major investment program in Garpenberg, which is now one of the most modern underground mines not only in Europe, but worldwide. Its resources, at a higher production level than ever before, will now last at least 25 years.

Boliden has presented yet another interesting volume to document the long scientific exploration process, which lead to the survival of the ancient operation for yet a few more decades. It should serve as an inspiration to all mining managements not to cut down on exploration whenever the going gets tough, but always remember that it is only through exploration that mines survive. With perhaps as much as $800-1000$ years of mine life, Garpenberg certainly demonstrates that also individual mines can be sustainable!
Magnus Ericsson

magnus@gladtjarnen.se

Luleå University of Technology, SE-971 87 Luleå, Sweden 